\title{
INFORMATION NEEDS AND USES: AN ANALYSIS OF THE LITERATURE PUBLISHED IN SPAIN, 1990-2004
}

\author{
A. González-Teruel , M.F. Abad-García \\ History of Science and Documentation Department, University of Valencia, Avenida Blasco \\ lbáñez, 15, 46010 Valencia, Spain
}

\begin{abstract}
This article presents a descriptive analysis of works published in Spanish journals and of the papers of conferences held in Spain in the field of information needs and uses in the period 1990-2004 in order to determine if the change in approach described by Dervin and Nilan, among others, also occurred outside the English speaking world. An analysis of the characteristics of relevant publications in this field (by year, authorship, type of document, type of work, and means of publication) shows that although activity is increasing, information needs and uses have not yet become a well-established area. In addition, a study of the content characteristics (by type of user, methodology used, aspects of the informationseeking process, use of a theoretical basis, and references to research) leads to the conclusion that in Spain there has not yet been a change in the orientation towards a user-oriented model.
\end{abstract}

\section{INTRODUCTION}

The first international publications studying information systems users and their information needs appeared in the first decades of the 20th century. However, it was not until the 1960s that the first studies appeared that looked at the information-seeking process from the point of view of the user (e.g., Taylor, 1968). Later, in the 1980s, there was a clearly discernible change in approach in information needs and uses studies. Two phases in this development can be distinguished. The first stage was characterized by, among other things, the publication of studies focused on requests made by particular groups of users. The aim of these studies was to obtain data that would facilitate determining patterns of information use that could then be applied to other groups. From the methodological point of view, this stage was characterized by a positivistic approach, and the techniques most frequently used were the survey and citation analysis. This approach was not without its critics (e.g., Brittain, 1982; Dervin \& Nilan, 1986; Herner \& Herner, 1967; Wilson, 1981), who were especially critical of its limited focus, and considered the methodologies used for the study of the interaction of individuals with the information to be inadequate. They also pointed out that the results obtained were rarely applicable to designing and improving information systems.

The second stage could be considered to be a reply to the limitations noted in the studies made up until that time. Thus, some researchers began to reconsider concepts that had been the subject of much debate (e.g., the need for information) and also began 
to build the first theoretical and methodological structures on which future research in this field would be based. Dervin and Nilan (1986) at that time described the development of a new approach, oriented towards the user, as an alternative to the previous one oriented towards the system. Although the previous descriptive orientation was not definitively abandoned, subsequent studies were more concerned with understanding informationseeking behavior from the global perspective of a user interacting with their surroundings, rather than quantifying transactions between the user and a specific information system (Hewins, 1990).

A key aspect of this research into information needs and uses was the fact that several theoretical proposals were developed to support the empirical research. As a result, "human information behavior, in comparison with other library and information science (LIS) sub-fields, is where researchers are among the highest users of theory" (McKechnie, Pettigrew, \& Joyce, 2000, p. 57). A fundamental characteristic of this useroriented approach was the introduction of qualitative assessment, which has resulted in greater knowledge about user interaction with information. This new approach has facilitated more complete and effective observation by means of the triangulation method (Wang, 1999), although earlier models were not abandoned. With regard to the quantity of publications produced in this field, the numbers vary according to the methodological model used in each study, the geographical area concerned, and the years being examined. Thus, for example, while Feehan, Havener, and Kester (1984) determined that $12.9 \%$ of the research articles published in LIS-related journals were devoted to users, Järvelin and Vakkari (1990) maintained that $8 \%$ of the research in this field was devoted to information seeking. The differences between countries are also significant. For example, while in countries such as Norway, Australia, Sweden, Denmark and Great Britain the quantity of publications in this field constitutes between $15 \%$ and $25 \%$ of the total of LIS literature (Rochester \& Vakkari, 1998), for others such as Turkey, the figures are around 7\% (Yontar \& Yalvaç, 2000).

There are other indications that lead one to conclude that this is currently a very active field. These include the publication of special issues devoted to information seeking or everyday life information seeking research in high profile journals (Journal of the American Society for Information Science and Technology; Library \& Information Science Research), the forthcoming publication of a special issue of the Journal of Documentation dedicated to human information behavior research (scheduled for late 2006), and the creation of special interest groups in associations such as the American Society for Information Science and Technology (which has such a group, called SIG-USE).

The situation just described reflects the general lines of international research into needs and uses, particularly in the English-speaking world, but does not necessarily reflect the overall situation. For example, in the case of Spain, Cano (1999) states that "in contrast to the plethora of users studies in mainstream Anglo-Saxon L\&IS, Spanish journals only devote $9.8 \%$ of their output to this topic" (p.677). Moreover, she claims that among the articles analyzed, none of them was devoted to the study of informationseeking behavior, and that those that were devoted to needs and uses research were studies based on reviewing inter-library loan requests made by scientists or engineers. It must also be noted that in the Spanish context, bibliometric studies still largely dominate the field of user studies. Indeed, the importance of bibliometric studies in Spanish research has been pointed out by Moya Anegón, Jiménez Contreras, and Moneda Corrachano (1998). 
The fact that there are differences in the case of Spain is understandable, as LIS only became an active field of research in the 1990s, as it was then that undergraduate and graduate LIS began to include modules devoted to the study of information users and needs. Specialized manuals were also published (González Teruel, 2005; Sanz Casado, 1994). Moreover, the large 3 number of specialized journals that have appeared in recent years, and the number of conferences that have been held in the LIS field, provide evidence that there has been some diversification in the subjects in which researchers and professionals are interested. Some of the conferences held in the 1990s included sections devoted to users, and indeed Spanish researchers presented the results of their research at ISIC, the most important international conference on information seeking (Maceviciute, 2002).

\section{PROBLEM STATEMENT}

Most of these observations remain to be proved, however, as the research work has not yet been done that would provide empirical data on Spanish needs and uses publications comparable to that found in Julien (1986) and Julien and Duggan (2000) for the Englishspeaking world. Thus, with the data currently available, it cannot be known if changes to the traditional approach and the search for theoretical models to orientate empirical research that have occurred in the English-speaking world have also occurred in Spain.

This article addresses the following research questions: What subjects are most frequently dealt with in Spanish information needs and uses literature? Do the characteristics of the publication of needs and uses literature provide evidence that Spanish LIS is becoming institutionalized? Do the studies of information needs published in Spain show a change in the traditional approach and a search for theoretical models to orientate empirical research as has occurred in the English-speaking world?

In order to address these questions this article presents a descriptive analysis of works published in Spanish journals, and of the papers of conferences held in Spain in the field of information needs and uses, in the period 1990-2004. The aim of this analysis is to establish, with a degree of certainty, the current state of needs and uses publications in Spain by relating them to specific characteristics described in other works published at an international level. This analysis is the first step towards determining what is lacking in order to orient future research along the lines of international developments in this field.

\section{PROCEDURE}

Two complementary search strategies were established for finding literature published in Spain on information needs and uses: These included an exhaustive search in the Spanish database ISOC Biblioteconomía y Documentación (ISOC-ByD) and a manual checking of the principal Spanish journals and conference papers. ISOC-ByD is a database developed by CINDOC (Centro de Información y Documentación Científica [Scientific Information and Documentation Center]) of CSIC (Consejo Superior de Investigaciones Científicas [Higher Scientific Research Council]), the principal Spanish research organization. This database includes references to articles in journals and conference papers devoted to LIS, archives, and scientific and information policies. It has the longest chronological coverage of any resource of its kind, and also includes the most important specialized Spanish publications. 
The bibliographical search, using the February 2005 version, covered the period 19902004. All of the terms that could characterize aspects of the information seeking process normally covered by the generic term "user studies" (Wilson, 1981, 1994) were translated into the system's language, and the search was carried out in the two fields:

- . The descriptor field, using descriptors for user studies, information needs, informationseeking behavior, information retrieval behavior, information use, library use, collection use, information requests, document requests, satisfaction, level of satisfaction, users and evaluation; and

- . The classification field: using the heading 201003, User studies.

Of the references found, all those that were published in Spanish journals and papers of conferences held in Spain, without regard to the geographical origins of the authors, were considered to be relevant, and included empirical studies designed to gather data on user conduct, bibliographical studies (e.g., bibliometric studies, and bibliographical updates) and theoretical, methodological, or conceptual studies.

All works that did not contain study and analysis of the information-seeking process from the point of view of the user were considered to be not relevant. These included, for example:

- Descriptions of activities and innovations in a library or documentation center;

- Discussions of library quality or evaluation systems that did not cover the role of the user in this process and which did not gather user information;

- Training for users or for information professionals;

- Descriptions of available Internet resources useful to specific user groups;

- Information policy documents;

- Technical processes for locating information; and

- Translations of articles originally published in other languages.

Subsequently, in order to avoid the possibility of bias in the selection of works obtained for analysis (whether due to the database indexing policies or to possible delays in updating it), the main Spanish LIS journals and the proceedings of the most important conferences held in Spain in this field (see Appendix I) were checked. In selecting these publications, their overall impact was taken into account, as well as the degree to which they reflected the Spanish research effort in LIS (Moya Anegón et al., 1998), and . whether or not they had a peer review system to select and screen submissions. In the course of this second process, the articles were selected according to the relevance criteria mentioned above. 
Table 1. Aspects analyzed in works obtained and considered relevant

\begin{tabular}{|c|c|}
\hline ASPECT ANALYZED & DEFINITION \\
\hline $\begin{array}{l}\text { 1) Temporal evolution of the } \\
\text { publications }\end{array}$ & Classification of the works by year of publication \\
\hline 2) Type of document & Journal article or conference paper \\
\hline 3) Means of publication & $\begin{array}{l}\text { - Academic journals published by a research organization or university departments } \\
\text { - } \quad \text { Professional journals published by a professional association }\end{array}$ \\
\hline 4) Authorship of the works & $\begin{array}{ll} & \text { University professor with teaching and research responsibilities } \\
\text { - } & \text { Full-time researchers } \\
\text { - } & \text { LIS professionals }\end{array}$ \\
\hline 5) Type of work. & $\begin{array}{l}\text { - Empirical: works that describe the systematic gathering of data on user behavior for a particular } \\
\text { purpose, such as the design or improvement of an information system. } \\
\text { - Bibliographical: bibliometric studies, bibliographical reviews, studies which analyze data obtained } \\
\text { by others (secondary studies) or consist of a bibliographical selection of a specific aspect of } \\
\text { information seeking behavior. } \\
\text { - Theoretical: Works that describe or propose a theoretical framework for studying user information } \\
\text { behavior. } \\
\text { - Methodological: Works establishing a basis for the application of one or more techniques for } \\
\text { studying information conduct of a group of users, or a methodological framework for evaluating a } \\
\text { service or center from the point of view of the user. }\end{array}$ \\
\hline 6) Type of user studied. & $\begin{array}{l}\text { - University based: teaching and research academics, and students. } \\
\text { - } \quad \text { Professionals: medical doctors, journalists, industrial workers, etc. } \\
\text { - } \quad \text { General users: usually public library users. } \\
\text { - } \quad \text { Researchers. } \\
\text { - }\end{array}$ \\
\hline 7) Methodological strategy* & $\begin{array}{l}\text { Experiment, survey (questionnaire and interview), observation (ethnography), transaction log analysis, } \\
\text { citation analysis, a mixture of two or more, other. }\end{array}$ \\
\hline $\begin{array}{l}\text { 8) Aspects of the information } \\
\text { seeking process }\end{array}$ & $\begin{array}{l}\text { - User attitude with regard to a service, system or source of information (regardless of whether or } \\
\text { not it is used) in order to determine whether the introduction of a specific information system is } \\
\text { likely to be successful (for example, attitude towards technology). } \\
\text { - Information needs or information required to carry out a specific task or resolve an information } \\
\text { problem, regardless of the information source selected to obtain the information. } \\
\text { - Information requests: actual requests made of a service, i.e. information obtained from the request } \\
\text { log with regard to the subject matter, type of document etc. that has been requested on an } \\
\text { information system. } \\
\text { - Use of a service, system or source of information: included under this heading are studies relating } \\
\text { to reading habits, the characteristics of a system, service or source, the frequency with which it is } \\
\text { used, Internet use, and usability, provided that the evaluation was made by evaluating a series of } \\
\text { criteria, not by the researcher. } \\
\text { - Use of the information. } \\
\text { - Level of satisfaction (user perception and opinion) with the use of the information or service, } \\
\text { system or source. }\end{array}$ \\
\hline 9) Use of a theoretical basis & Discussion or use of a theoretical, methodological or conceptual basis for studying users. \\
\hline
\end{tabular}

* In order to ensure comparability and consistency, the classification used by Julien (1996) and Julien and Duggan (2000) was used.

${ }^{* *}$ The definition of the information seeking process used here is the following: "A sequence of stages through which a person passes from the moment they perceive a lack of information that prevents them from solving a problem until they use this information in order to solve this problem" (González Teruel, 2005)

Table 1 shows the aspects of the works thus obtained that were analyzed. With regard to the last item analyzed, "Use of a theoretical basis," a single list was compiled from the theories and models generally used in LIS, as seen in the reviews by Pettigrew and McKechnie (2001), Gómez Pantoja (2003), and Jeong and Kim (2005). The various 
theories and models specific to the field of information behavior found in Fisher, Erdelez, and McKechnie (2005) were also included. An examination of the previously mentioned works resulted in a list of 329 theories and models. These were then compared with those used in the works analyzed as a:

- Basis for the design of an empirical study;

- Reference included in a bibliographical review;

- Basis for examining the various methodological strategies used in studies of this kind (for example, a timeline interview); and

- Basis for a theoretical study on user information behavior.

In addition, an attempt was made to determine to what extent the change in approach described for the English-speaking world was noticeable in Spanish needs and uses publications. A check was therefore made of the extent to which references in the publications studied were to those works cited by McKechnie, Goodall, Lajoie-Paquette, and Julien (2005) as being those most referred to in the field of human information behavior in the 1990s (see Appendix II) and whether or not reference was made to the two most important works in this field that have appeared in recent years, those of Wilson (1981) and Dervin and Nilan (1986).

A random sample of 30 articles (approximately $25 \%$ of the articles finally examined) was then also coded by an independent researcher. The final percentage of agreement for all coding decisions was $89.0 \%$, which suggests that the coding classification used was reliable.

\section{RESULTS}

The search of the ISOC-ByD database produced 305 items, of which 91 (29.8\%) were considered relevant. The excluded items were distributed as follows, using the criteria discussed above:

- Description of activities and services (86 items)

- Training for users or professionals (60 items)

- Quality control or evaluation systems (17 items)

- Internet resources on a subject (3 items)

- Information policies (12 items)

- Technical processes for finding information (7 items)

- Translations of works that had originally appeared in non-Spanish publications (3 items)

- Other miscellaneous reasons (25 items)

Subsequently, a total of 2,905 journal articles and conference papers were checked and 103 items were found, of which 32 had not appeared in the ISOC-ByD database search. The number of items finally analyzed was 123 . 
In spite of some fluctuations, during the period analyzed there was an overall upwards trend for the output of works published (Figure 1). The average number of works published per year is 8.2. The year with the largest number of works published was 1999, with 22. This exceptional output was due, in part, to the increase in the number of papers submitted to conferences (Table 2). From this year on, output declined. In recent years, however, production has increased, and 10 works were published in 2004.

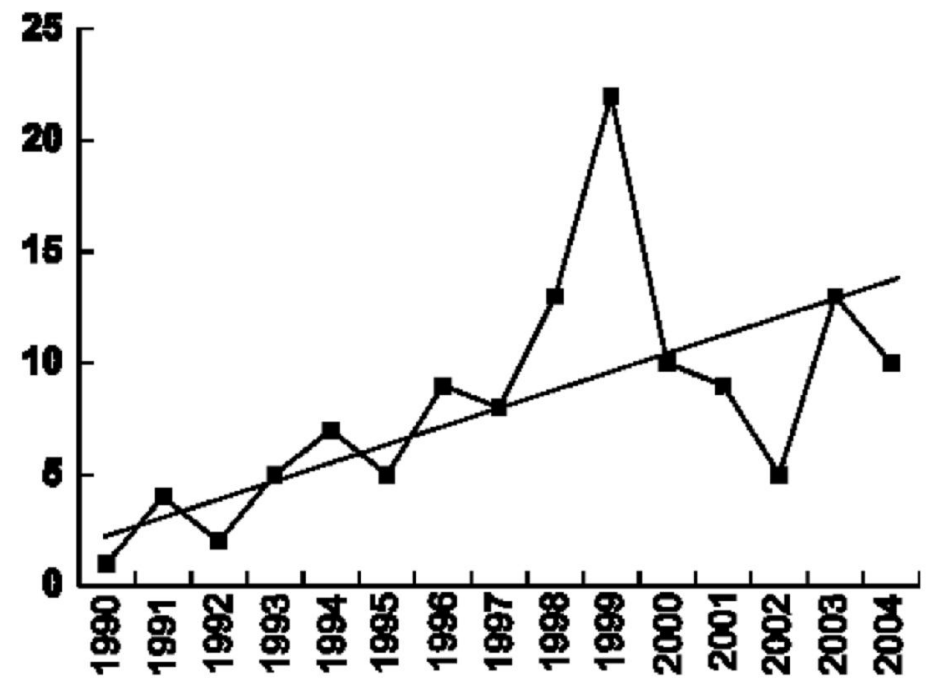

[Table2. Type of work by year of publication.

\begin{tabular}{l|rrr}
\hline Year & $\begin{array}{c}\text { Journal } \\
\text { article }\end{array}$ & $\begin{array}{c}\text { Conference } \\
\text { paper }\end{array}$ & Total \\
\hline 1990 & 1 & & 1 \\
1991 & 4 & & 4 \\
1992 & 2 & & 2 \\
1993 & 5 & 7 & 5 \\
1994 & & 4 & 5 \\
1995 & 1 & 5 & 9 \\
1996 & 4 & 2 & 8 \\
1997 & 6 & 9 & 13 \\
1998 & 4 & 13 & 22 \\
1999 & 9 & 3 & 10 \\
2000 & 7 & 2 & 9 \\
2001 & 7 & 1 & 5 \\
2002 & 4 & 9 & 13 \\
2003 & 4 & & 10 \\
2004 & 10 & 55 & 123 \\
\hline TOTAL & 68 & & \\
\hline
\end{tabular}


Of the 123 documents analyzed, $68(55.3 \%)$ were original articles and 55 (44.7\%) were conference papers. Almost two thirds $(64.7 \%)$ of the articles published in journals appeared in academic journals, whereas $35.3 \%$ were published in professional journals. Most of the first authors were university staff $(48.8 \%)$, whereas $25.2 \%$ were LIS professionals (22 belonged to university libraries, $70.9 \%$ of the LIS professionals) and $18.7 \%$ were full-time researchers (12 CSIC researchers, $52.2 \%$ of the full-time researchers).

\section{Table 3. Type of author]}

\begin{tabular}{l|rr}
\hline Type of author & $\mathrm{N}$ & \multicolumn{1}{c}{$\%$} \\
\hline University staff & 60 & 48.8 \\
LIS & 31 & 25.2 \\
Professional & & \\
Researcher & 23 & 18.7 \\
Don't know & 9 & 7.3 \\
\hline Total & 123 & 100 \\
\hline
\end{tabular}

Most of the works (72.4\%) were empirical studies, which presented the results of research into information seeking of various user groups. Methodological studies represented $13.8 \%$ and 7 bibliographical studies $10.6 \%$ of the total. Only four works (3.3\%) presented theoretical frameworks for studying information behavior (Table 4).

\section{Table 4. Type of work]}

\begin{tabular}{l|rr}
\hline & \multicolumn{2}{|c}{$\%$} \\
& No. & \\
\hline Empirical & 89 & 72.4 \\
Methodological & 17 & 13.8 \\
Bibliographical & 13 & 10.6 \\
Theoretical & 4 & 3.3 \\
\hline Total & 123 & 100 \\
\hline
\end{tabular}

Almost half $(48.3 \%)$ of the 89 empirical studies that researched some aspect of the information seeking process were concerned with university-based users. Of these, 12 focused on students, 10 on research or teaching staff, and 21 did not specify the user type. The remaining works were about other types of users, as shown in Table 5 . It is significant that half of the studies (4 items) that researched some aspect of the information seeking process by professionals were focused on health professionals, and most of the studies included in the category Business/Industry were centered on the pharmaceutical industry.

Table 5. Type of user researched.

\begin{tabular}{l|lr}
\hline & \multicolumn{2}{|c}{ No. } \\
\hline University based & 43 & 48.3 \\
\hline
\end{tabular}




\begin{tabular}{l|rr}
\hline Professionals & 8 & 9.0 \\
Business / Industry & 7 & 7.9 \\
General users & 5 & 5.6 \\
Researchers & 4 & 4.5 \\
Other & 3 & 3.4 \\
More than one group & 2 & 2.2 \\
Not specified & 17 & 19.1 \\
\hline Total & 89 & 100 \\
\hline
\end{tabular}

Figure 2 shows the various methodological strategies used in the 89 empirical studies. Of these, $85(95.5 \%)$ used one methodology only, and four $(4.5 \%)$ used two or more. Although various different methodological approaches were used, in only one case was triangulation the stated methodological strategy. In the other three cases, the methodology was circumstantial, for example the study was carried out by means of a survey. In some cases a self-administered questionnaire was used for the convenience of the researchers, whereas on other occasions a personal interview was carried out.

\section{Figure 2. Methodological strategies.}

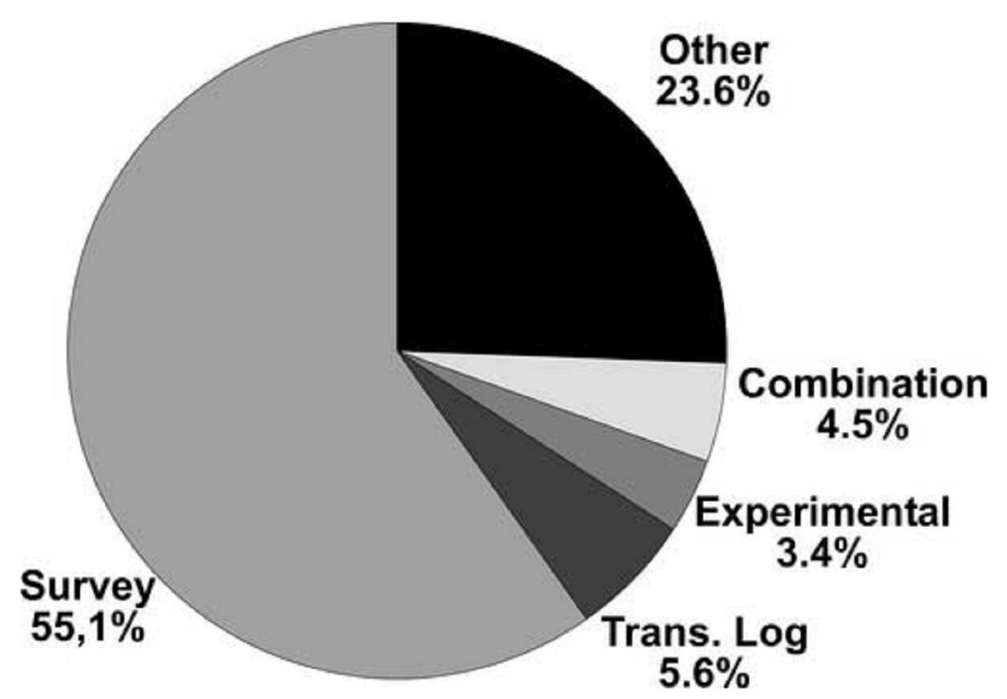

In $55.1 \%$ of the cases, surveys were the methodological strategy. In 17 of these cases the method of administration was not specified, in 22 cases the survey was administered by means of a self-administered questionnaire, and in 10 cases the researchers relied on personal interviews. In three cases, questions were devised using the critical incident technique. 
The remaining methodological strategies were few in number. The category of "other" $(23.6 \%)$ is noteworthy. Included in this category are records of requests made to an information service. Surveys and "other" make up $78.7 \%$ of the strategies used.

In considering the aspect researched (Table 6), when one single aspect was studied, requests made of a service dominated $(24.7 \%)$, along with the use made of a service, system or information source (27.0\%). Together, these represents $51.7 \%$ of the total.

Table 6. Aspects of the information seeking process researched

\begin{tabular}{l|rr}
\hline & No. & $\%$ \\
\hline One aspect & & 1.1 \\
User attitude to a service, system or source of information & 5 & 5.6 \\
Information needs & 22 & 24.7 \\
\hline Actual requests made of a service & 24 & 27.0 \\
Use of a service, system or information source & 9 & 10.1 \\
\hline Use of information & 2 & 2.2 \\
Satisfaction & 1 & 1.1 \\
More than one aspect & 3 & 3.4 \\
Attitude to a service + User of a service, system or information source & 1 & 1.1 \\
Information needs + Use of a service, system or information source & 1 & 1.1 \\
Actual requests made of a service + Use of a service, system or information source & 20 & 22.5 \\
\hline Use of a service, system or information source + Use of information & 89 & 100 \\
\hline Use of a service, system or information source + Satisfaction & \multicolumn{2}{|c|}{} \\
\hline Total & & \\
\hline
\end{tabular}

When more than one aspect was studied, the most common (22.5\%) was the combination "Use of a service, system or information source" + "Satisfaction study." The latter group, together with "Requests and use," represents $74.2 \%$ of the total.

Table 7 shows that $14(14.0 \%)$ of the works mentioned one of the theories and models included in the previously compiled list. Of the 89 works that presented empirical results, only five (5.6\% of the empirical studies, $4 \%$ of the total) based their observations on a theoretical framework. The theoretical frameworks used were:

- Diffusion Theory;

- Information Seeking in Electronic Environments (Marchionini);

- Models of multiple associationism (specifically the Kohonen algorithm);

- The Bradford Law of Scattering; and

- Parasuraman Conceptual Service Model. 
Table 7. Use of a theoretical basis in Spanish literature on information needs and uses

\begin{tabular}{l|ccrrr}
\hline & \multicolumn{2}{|c}{ Theoretical basis } & \multicolumn{2}{c}{$\begin{array}{c}\text { Without } \\
\text { theoretical } \\
\text { basis }\end{array}$} & Total \\
& $\begin{array}{l}\text { Present in the } \\
\text { comparison list }\end{array}$ & $\begin{array}{c}\text { Theoretical basis } \\
\text { proposed by the } \\
\text { researcher }\end{array}$ & & \\
\hline Empirical & 5 & & 84 & 89 \\
Methodological & 3 & & 14 & 17 \\
Bibliographical & 4 & 2 & 9 & 13 \\
Theoretical & 2 & 2 & 0 & 4 \\
\hline Total & 14 & $(1.6 \%)$ & 105 & 123 \\
& $(14.0 \%)$ & & $(85.4 \%)$ & $(100 \%)$ \\
\hline
\end{tabular}

Finally, only five articles referenced any of the works most often cited in the 1990s according to McKechnie et al. (2005). With regard to the works of Wilson (1981) and Dervin and Nilan (1986), only two included the former in their bibliography, and only one included the latter.

\section{DISCUSSION}

One of the first aspects that became apparent when undertaking this research was the difficulty in obtaining precise retrieval data on the subject of information needs and uses when using specialized information sources such as ISOC-ByD. In the course of this research, the indiscriminate use of the descriptor "user studies" was noted, not only to index works which do in fact set out to study users and their needs, but also those which deal with training users and information professionals or the introduction of quality assessment systems. This may be due to a lack of recognition of the subjects that are characteristic of this research area, which in turn results from a lack of development in the field of needs and uses research. Instead, studies have concentrated on other areas, such as information retrieval or scientific and professional communication, as suggested by the study made by Cano (1999).

Manual checking carried out in various journals and conference papers facilitated the retrieval of a large percentage $(26.02 \%)$ of the items. Possible explanations for this are that the journal or conference had not been indexed, or was indexed with descriptors not included in the search strategy, or was present in the database but still not assigned descriptors, or the database simply had not included it for unknown reasons. Using the ISOC-ByD database alone, therefore, it would not have been possible to include such papers in the analysis. This highlights the inadequacy of ISOC-ByD as a single source for the study of Spanish LIS, as has already 9 been pointed out (Guallar Delgado, 2003; Jiménez Contreras \& Moya Anegón, 1997). When interpreting the statistics relating to the total number of publications analyzed and their development during the period under discussion, some factors that particularly affect the Spanish development of LIS should be taken into account. 
During the 1990s, LIS was rapidly established as a recognized academic field in Spain. This is a key factor in explaining the differences in LIS research in other countries (Rochester \& Vakkari, 2003). In the case of Spain, it was only from the 1980s onwards that university studies in LIS were established, and in the 1990s when B.A. and Ph.D. qualifications were institutionalized. It was also in this last decade when most of the Spanish professional associations were set up. At the same time, there was an increase in the number of professional and scientific publications, thanks to an increase in formal means of dissemination, such as scientific journals, conferences, and specialist publishers (Delgado López Cózar, 2003).

It is not surprising, therefore, that the number of works published on information needs and uses in Spain increased from just one at the beginning of the decade to 22 in 1999. This increase was due mostly to conference papers that resulted from an enormous impetus to organize such events during the late 1990s (Delgado López Cózar, 2003). For the same reasons, most of the authors were university teachers. This is in line with other studies previously carried out in Spain (Jiménez Contreras \& Moya Anegón, 1997; Frías Montoya \& Romero Gómez, 1998), although this is not generally the case at an international level (Julien, 1996; Julien \& Duggan, 2000). This reflects an increase in productivity on the part of those active in this field after the progressive introduction of LIS studies in Spanish universities.

If only those works published in journals are examined, it can be seen that most of them were published in journals that can be classified as academic, contrary to the findings of Julien and Duggan (2000). Spanish literature on needs and uses could therefore be considered to be an "academic subject." Case (2002) also considers it to be so, and finds that the usefulness of this type of research is still not evident among professionals in this field.

The contents of the works examined offer evidence of a broader range than the narrow findings of Cano (1999), that is, studies based on counting the inter-library lending requests of scientists and engineers. They are, nevertheless, more closely related to the systems paradigm described by Dervin and Nilan (1986) than to the new research trends devoted to searching for theoretical models for the empirical study of information behavior.

University users predominate, and represent almost half of the studies. As Case (2002) confirms, although there are many studies with this group as a subject, they do not use a common methodology, and it is therefore not possible to obtain comparable results. This in turn impedes progress being made in research. As Julien and Duggan (2000) also point out, it 10 remains to be seen whether greater attention has been given to this group for theoretical reasons, or merely for convenience, given that the university community is also the most accessible.

One particularly notable factor in this respect, however, is the number of areas that are not covered in the works analyzed. There is a lack, for example, of studies that deal with aspects of the information seeking process with students at different university levels. This could be because of the fact that the academic library is not a properly established part of the Spanish education system. This fact also highlights the lack of coordination between the students' learning processes and access to information, a matter that is firmly part of the education and library systems in the English speaking world (Bunge \& Bopp, 2001). Moreover, there were no studies focused on the information needs of the ordinary citizen, 
or of patients with a particular pathology, or studies focused on disadvantaged, ethnic or immigrant groups.

The survey was the most frequently used methodological strategy, in line with LIS at an international level (e.g., Dimitroff, 1993; Jarvelin \& Vakkari, 1993). Questionnaire and interviews were also the method most used in the needs and uses field according to the findings of Julien (1996) and Julien and Duggan (2000). The present study, however, highlights the fact that a large number of works that used the survey methodology did not describe how it was administered (17). Delgado Lopez-Cózar (2004) pointed out this lack and other similar omissions in survey-based research work in the period 1976-1997. He attributed this to two causes: a) the lack of methodological training of LIS Spanish researchers, and $b$ ) the lack of effective peer review systems in journals and conferences.

Another important characteristic of the methodology used is the little use made of the triangulation method in the works examined, although its suitability for the study of users has been highlighted by various authors (e.g., Fidel, 1993; Wang, 2001). According to Julien (1996) and Julien and Duggan (2000), in the period 1984-1998, an average of $13.8 \%$ of research reported in the field of information needs and uses used this method.

The fact that in the present study, the triangulation method was specifically mentioned only once indicates a certain lack of maturity. The predominance of the bibliometric approach in Spanish research must also be noted (Moya Anegón et al., 1998). There is, therefore, even today, a real preference for the quantitative model in LIS in Spain, with consequent effects on the study of users. The fact that three research studies used the critical incident technique suggests that things are changing. This was also noted some time ago by Hewins (1990). However, the time gap between that researcher's observation (which referred to works published in the late 1980s) and 15 years later (referring to works covered by this study) suggests that the delay is considerable.

With regard to the aspects of the information-seeking process observed, it is clear that those which were most evident were those which were of the most interest at that time, (i.e., requests), and the use made of specific information systems, including the user's satisfaction with the system. This is precisely what many authors consider to be the focus of systemoriented studies (e.g., Bruce, 2002), and is far from the holistic vision described by Dervin and Nilan (1986) as one of the characteristics of the new, user-oriented model. Other, more important aspects of information systems design and planning, such as needs and information problems, have been ignored as well. There is, therefore, an enormous gulf between the Spanish publications analyzed and the results presented by Julian and Dugan (2000), who indicated that almost $48 \%$ of the works they analyzed were related to systems design.

The results concerning the aspect of the information-seeking process studied may be closely related to those concerning the theory used to study users. In only $14 \%$ of the works analyzed (5.6\% of the empirical studies) is any reference made to the various theories mentioned in international LIS studies. This figure is well below the $58.9 \%$ indicated for theoretical articles in human information behavior literature according to McKechnie et al. (2000). Thus, the lack of a theoretical basis in Spanish needs and uses literature explains to a large extent the fact that research has centered on physical aspects of the information-seeking process, and has omitted other aspects more closely related to the cognitive or attitude dimensions of the user when seeking information. It should be 
noted that the Sense-Making theory or Kulthau's Information Seeking Process theory were not taken into account in the empirical studies of users, in spite of being those most often cited in information science research (Pettigrew \& McKechnie, 2001). Moreover, the extent to which Spanish needs and uses literature differs from current international trends is clear from the lack of references to the works that have been fundamental in the last two decades, those of Wilson (1981) and Dervin and Nilan (1986), as well as the few references made in to the most often cited articles on human information behavior according to McKechnie et al. (2005).

\section{CONCLUSION}

The results show that the study of information needs and uses in Spain still falls short of being a consolidated area, as evidenced by both the low volume of publications and the means of disseminating the research, given the high proportion of conference papers as opposed to journal articles. It is clear that there has not yet been a change in the orientation towards a useroriented model. The results obtained by the analysis indicate that the increase in theoretical activity in the 1990s referred to by Fisher et al. (2005) has not yet reached Spain. Given the situation described in this study, it is essential to include the following areas in the research agenda, as a minimum:

- Critical analyses of needs and uses literature published in Spain. Although this analysis has been begun here, it should be complemented with a review of other papers presented at conferences held during the last few years, and should include doctoral theses, specialized manuals, and monographs.

- Undertaking new research that provides knowledge of other users, apart from those already studied, and application of the results to improving the various types of information systems.

- Establishment of a qualitative approach to the study of users by means of developing new means of observation more suited to the study of human behavior.

- Study and analysis of the various theoretical models and methodologies proposed in recent years, as exemplified by the recent work of Fisher et al. (2005). This should include initiating empirical research that demonstrates the validity of such models, and enables them to be improved on the basis of the experience thus obtained.

The lines of research suggested here should be within the framework of the process of consolidating LIS studies that began in Spain at the end of the 1980s and the beginning of the 1990s. This process should lead to the recognition of LIS as a scientific discipline. In the specific case of the study of needs and uses of information, this should result in broadening the terms of reference with which these studies are carried out and their results applied. Similarly, such research should be designed more rigorously, and the traditional quantitative orientation extended by the introduction of the triangulation method. Finally, the recognition of a widely accepted theoretical basis would serve as a guide to empirical research, and would channel it in the direction of projects of value to the user. 


\title{
APPENDIX
}

\section{JOURNALS AND CONFERENCE PAPERS CHECKED.}

\author{
a) JOURNALS
}

- Anales de documentación

- Bid: textos universitarios de biblioteconomia i documentació

- Boletín de la Anabad

- Boletín de la Asociación Andaluza de Bibliotecarios

- Cuadernos de documentación multimedia

- Cybermetrics

- Documentación de las ciencias de la información

- El profesional de la información

- Item: revista de bibloteconomía i documentació

- Revista española de documentación científica

- Revista general de información y documentación

b) CONFERENCES

- Jornadas españolas de documentación

- Jornades catalanes de documentació

- Congreso nacional de ANABAD

- Jornadas bibliotecarias de Andalucía

\section{MOST FREQUENTLY CITED INFORMATION BEHAVIOR ARTICLES}

(McKechnie, E.F., Goodall, G.R., Lajoie-Paquette, D. \& Julien, H., 2005).

Bates, M. J., Wilde, D. N., \& Siegfried, S.L. (1993). An analysis of search terminology used by humanists: The Getty Online Search Project report number 1. Library Quarterly, 63(1), $1-39$.

Byström, K, \& Järvelin, K. (1995). Task complexity affects information seeking and use. Information Processing \& Management, 31, 191-213.

Chatman, E. A. (1996). The impoverished life-world of outsiders. Journal of the American Society for Information Science and Technology, 47, 193-206.

Ellis, D., Cox, D., \& Hall, K. (1993). A comparison of the information seeking patterns of researchers in the physical and social sciences. Journal of Documentation, 49, 356-369.

Gorman, P.N. (1995). Information needs of physicians. Journal of the American Society for Information Science, 46, 729-736.

Kuhlthau, C. C. (1993). A principle of uncertainty for information seeking. Journal of Documentation, 49, 339-355. 
Leckie, G. J., Pettigrew, K.E., \& Sylvain, C. (1996). Modeling the information seeking of professionals: A general model derived from research on engineers, health care professionals, and lawyers. Library Quarterly, 66(2), 161-193.

Savolainen, R. (1993). The sense-making theory: Reviewing the interests of a usercentered approach to information seeking and use. Information Processing \& Management, 29, 13- 28.

Savolainen, R. (1995). Everyday life information seeking: Approaching information seeking in the context of "Way of Life". Library \& Information Science Research, 17, 259-294.

Schacter, J., Chung, G. \& Dorr, A. (1998). Children's Internet searching on complex problems: Performance and process analyses. Journal of the American Society for Information Science and Technology, 49, 840-849.

Wilson, T. D. (1997). Information behavior: An interdisciplinary perspective. Information Processing \& Management, 33, 551-572.

Wilson, T. D. (1999). Models in information behaviour research. Journal of Documentation, 55, 249-270.

\section{REFERENCES}

Brittain, J.M. (1982). Pitfalls of user research, and some neglected areas. Social Science Information Studies, 2, 139-148.

Bruce, H. (2002). The user's view of the Internet. Lanham, MD: Scarecrow Press.

Bunge, C.A., \& Bopp, R.E. (2001). History and varieties of reference services. In R. E. Bopp, \& L. C. Smith (Eds.), Reference and information services: An introduction (pp. 3-26). 3rd ed. Englewood, Co: Libraries Unlimited.

Cano, V. (1999). Bibliometric overview of library and information science research in Spain. Journal of the American Society for Information Science, 50, 675-680.

Case, D.O. (2002). Looking for information: A survey of research on information seeking, needs and behavior. San Diego, CA: Academic Press.

Delgado López-Cózar, E. (2003). Las cifras de la documentación en España: 2002. El profesional de la información, 12, 344-367.

Delgado López-Cózar, E. (2004). La investigación por encuesta en la biblioteconomía y documentación española: Análisis de las encuestas publicadas en revistas y congresos de la especialidad entre 1976 y 1997. In J.A. Frías \& A.B. Ríos Hilario (Eds.), Metodologías de investigación en información y documentación (pp. 80-135). Salamanca: Universidad de Salamanca. 
Dervin, B., \& Nilan, M. (1986). Information needs and uses. In M. Williams (Ed.), Annual Review of Information Science and Technology (Vol. 21, pp. 3-33). White Plains, NY: Knowledge Industry Publications.

Dimitroff, A. (1992). A research in health sciences library and information sciences: A quantitative analysis. Bulletin of the Medical Library Association, 80, 340-346.

Feehan, P.E., Havener, W.M., \& Kester, D.D. (1987). Library and Information Science Research: An analysis of the 1984 journal literature, Library \& Information Science Research, 9, 173-185.

Fidel, R. (1993). Qualitative methods in information retrieval research. Library \& Information Science Research, 15, 219-247.

Fisher, K.E., Erdelez, S., \& McKechnie, E.F. (Eds.). (2005). Theories of information behavior. Medford, NJ: Information Today.

Frías Montoya, J.A., \& Romero Gómez, P. (1998) ¿Quiénes son y qué citan los investigadores que publican en las revistas españolas de biblioteconomía y documentación? Anales de Documentación, 1, 29-53. Retrieved May 8, 2006, from http://www.um.es/fccd/anales/ad01/ad0104.htm

Gómez Pantoja, A. (2003). Aportación teórica a la biblioteconomía de los estudios centrados en el usuario: Library \& Information Science Research (1977-2002), Forinf@. Revista Iberoamericana de usuarios de información, 19-20, 5-38.

González Teruel, A. (2005). Los estudios de necesidades y usos de la información: Fundamentos y perspectivas actuales. Gijón: Trea.

Guallar Delgado, J. (2003). Mètodes i tècniques de recerca en els articles de documentació periodística a Espanya (1997-2002). BiD, Textos universitaris de biblioteconomia i documentació, 11. Retrieved May 8, 2006, from http://www.ub.es/bid/11 gualla.htm

Herner, S., \& Herner, M. (1967). Information needs and uses in science and technology. In C. A. Cuadra (Ed.), Annual Review of Information Science and Technology (Vol. 2, pp. 134). New York: Interscience.

Hewins, E. T. (1990). Information need and use studies. In M. E. Williams (Ed.), Annual Review of Information Science and Technology (Vol. 25, pp. 145-172). New York: Elsevier.

Jaervelin, K., \& Vakkari, P. (1990). Content analysis of research articles in library and information science. Library \& Information Science Research, 12, 395-421.

Jeong, D.Y., \& Kim, S.J. (2005). Knowledge structure of library and information science in South Korea. Library \& Information Science Research, 27, 51-72 
Jiménez Contreras, E., \& Moya Anegón, F. (1997). Análisis de la autoría en revistas españolas de biblioteconomía y documentación, 1975-1995. Revista Española de Documentación Científica, 20, 252-266.

Julien, H. (1996). A content analysis of the recent information needs and uses literature. Library \& Information Science Research, 18, 53-65.

Julien, H., \& Duggan, L.J. (2000). A longitudinal analysis of the information needs and uses literature. Library \& Information Science Research, 22, 291-309.

Maceviciute, E. (2002). Review of Lars Höglund and Tom Wilson, Eds., The new review of information behaviour research. Vol. 2: Studies of information seeking in context ISIC III, The third international conference on research in information needs, seeking and use in different contexts, Goteborg, 2001. London: Taylor-Graham, 2001. Information Research, 7(3). Retrieved May 8, 2006, from http://informationr.net/ir/reviews/revs054.html

McKechnie, L., Goodall, G.R., Lajoie-Paquette, D., \& Julien, H. (2005). How human information behaviour researchers use each other's work: A basic citation analysis study. Information Research, 10(2), paper 220. Retrieved, May 8, 2006, from http://InformationR.net/ir/10-2/paper220.html

McKechnie, L., \& Pettigrew, K. (2002). Surveying the use of theory in library and information science research: A disciplinary perspective. Library Trends, 50, 406-417.

McKechnie, L., Pettigrew, K., \& Joyce, S. (2000). The origins and contextual use of theory in human information behavior research. The New Review of Information Behavior Research: Studies of Information Seeking in Context, 2, 47-63.

Moya Anegón, F. de, Jiménez Contreras, E., \& Moneda Corrachano, M. de la. (1998). Research fronts in library and information science in Spain (1985-1994). Scientometrics, 42, 229- 246.

Pettigrew, K., \& McKechnie, L. (2001). The use of theory in information science research. Journal of the American Society for Information Science and Technology, 52, 62-73.

Rochester, M. K., \& Vakkari, P. (1998). International LIS Research: A comparison of national trends. IFLA Journal, 24, 166-175.

Rochester, M.K., \& Vakkari, P. (2003). International Library and Information Science Research: A Comparison of National Trends. IFLA Professional Reports, Nr. 82. Retrieved May 8, 2006, from http://www.ifla.org/VII/s24/pub/iflapr-82-e.pdf

Sanz Casado, E. 1994. Manual de estudios de usuarios. Madrid: Fundación Germán Sánchez Ruipérez.

Taylor, R. (1968). Question-negotiation and information seeking in libraries. College and Research Libraries, 29, 178-194. 
Wang, P. (2001). Methodologies and methods for user behavioral research. In M. Williams (Ed.), Annual Review of Information Science and Technology (Vol. 34, pp.53-99). Medford: Information Today.

Wilson, T. D. (1981). On user studies and information needs. Journal of Documentation, 37, 3- 15.

Wilson, T. D. (1994). Information needs and uses: Fifty years of progress? In B. C. Vickery (Ed.), Fifty years of information progress: A Journal of Documentation review (pp.15-52). London: ASLIB.

Yontar, A., \& Yalvac, M. (2000). Problems of library and information science research in Turkey: A content analysis of journal articles 1952-1994. IFLA Journal, 26, 39-51. 